\title{
RIGHT TO BE PUNISHED?
}

\author{
Adriana Placani \\ University of Graz \\ Stearns Broadhead \\ University of Graz \\ Original scientific article - Received: 12/02/2020 Accepted: 7/6/2020
}

\begin{abstract}
It appears at least intuitively appropriate to claim that we owe it to victims to punish those who have wronged them. It also seems plausible to state that we owe it to society to punish those who have violated its norms. However, do we also owe punishment to perpetrators themselves? In other words, do those who commit crimes have a moral right to be punished? This work examines the sustainability of the right to be punished from the standpoint of the two main theories of rights-the will and the interest conceptions. The right to be punished is shown to be largely indefensible on both accounts: on the will theory, the right to be punished conflicts with autonomy, and it can neither be claimed nor waived by a perpetrator; on the interest theory, a perpetrator's interest in punishment, inasmuch as it exists, is not sufficient to ground a duty on the part of the state.
\end{abstract}

Keywords: Punishment; right to be punished; Duff; communicative theory of punishment; rights; will theory; interest theory

\section{Introduction}

It seems at least intuitively right to claim that we owe it to victims to punish those who have wronged them. It also seems plausible to say that we owe it to society to punish those who have flouted its norms. However, can it be said that we owe punishment to perpetrators themselves? That is, and 
this might sound odd at first, can we assert that those who commit crimes have a moral right to be punished? The idea of a right to be punished has a long history ${ }^{1}$ that stretches into the present. Contemporary advocates of the right include Christopher Bennett (2008), Thom Brooks (2013), Gabriel Hallevy (2013), and Antony Duff (1986; 2000; 2001; 2003).

This article considers the defensibility of the right to be punished from the standpoint of the will and interest theories of rights, and shows the right to be largely indefensible on both theories. On the will theory, the right to be punished conflicts with autonomy and a perpetrator can neither claim nor waive it. On the interest theory, a perpetrator's interest in punishment, inasmuch as it exists, is not sufficient to ground a duty on the part of the state. Although this work primarily focuses on Duff's conception of punishment and perpetrators' right to it (to the exclusion of other conceptions), its analysis brings much needed clarification to an idea oftentimes plagued by loose and vague language.

The structure of this essay is as follows. The first section explicates the right to be punished and the role of this particular right in Duff's communicative theory of punishment, which is selected because of its considerable influence in the contemporary literature. This section also clarifies other main concepts and definitions used throughout. The second section argues against the idea that perpetrators have a right to be punished. It shows that the will-based theory cannot plausibly sustain the right. It also briefly addresses aspects of Duff's communicative theory of punishment and points out how arguments against the right to be punished affect it. Much like the second section, the third argues against the right to be punished, but it does so in accordance with the interest-based theory. This section also connects these arguments to Duff's broader account. Finally, a short conclusion ends this work.

\section{Anthony Duff's Theory and the Right to be Punished}

The right to be punished seems like the height of humanity to some and the pinnacle of preposterousness to others. Those in the first camp often claim that the right to be punished arises out of the idea that all persons, including criminals, ought to be treated as responsible moral agents to whom respect is owed (Dubber 1998). On this view, then, punishment broadly amounts to a way of showing respect for fellow human beings. Those in the second camp often begin their attacks by pointing out that the right to be punished

\footnotetext{
${ }^{1}$ See Dubber (1998) for an overview on the philosophical history of the right to be punished.
} 
makes very little sense (see Bagaric and Amarasekara 2000; Deigh 1984; Feinberg 1974). This is because it seems implausible that a right-holder would exercise a right that would deprive her of liberty and cause her suffering. It seems more sensible that there would be a right against such things. ${ }^{2}$

A contemporary advocate of the right to be punished is Antony Duff, whose communicative theory of punishment includes this right. His theory can be summarized as follows. For Duff, punishment is and ought to be a communicative process aimed at engaging the perpetrator in a moral dialogue about her crime $(2011,372)$. Punishment endeavors to communicate to the perpetrator a proper understanding of the wrongdoing she committed and bring her (i.e., the offender) to communicate that repentant understanding to her fellow citizens (Duff 2000, 412).

\section{In Trials and Punishment, Duff writes that a}

sane offender has a right to be punished: a right to be punished rather than be subjected to some kind of manipulative or preventive treatment which would not address him as a rational agent. (Duff 1986, 283)

In more recent works, Duff's emphasis on this right is lessened, but remains a part of his theory. In his article, "In Defense of One Type of Retributivism", Duff clarifies his previous elaborations on the right to be punished:

To talk of a 'right' to be punished is to talk of punishment as something that is owed to the offender (not just, for instance, to the victim or the wider community), and as something that is supposedly for her own good (not just as something that she deserves). Perhaps it is also to imply that punishment is something that the offender would claim for herself, if she realised the truth. (Duff 2000, 418)

Duff seems to argue in favor of the right to be punished from a number of vantage points. First, we owe punishment to a perpetrator out of respect for her as a responsible moral agent. Society owes it to a perpetrator to treat

\footnotetext{
${ }^{2}$ See Husak (2008, 92-103) arguing about a right not to be punished.

${ }^{3}$ Note that Duff attempts to persuade the reader further by comparing his reliance on the right to be punished to alternatives such as ignoring perpetrators' crimes or subjecting perpetrators to measures aimed at preventing them from repeating their wrongdoings. To this, it is unclear both why the right should be considered only in light of alternatives and why it should be considered only in light of the alternatives suggested by Duff.
} 
her as a responsible member of the political community (Duff 2003, 305). Second, punishment is also owed to the perpetrator because it is supposedly for her own good (as opposed to being something that she deserves) (Duff 2000, 417-418). Finally, punishment is something that the perpetrator would claim for herself (if she realized that it was for her own good) (Duff 2000, 418). These standpoints can be generalized so as to fit with the two main theories of rights on the basis of which the right to be punished will be assessed.

Before going further, however, the purpose of punishment can be clarified. After all, whether or not there is a right to be punished depends in part on what that right amounts to - a right to what exactly? In keeping with Duff as well as others who have focused on this topic, it is only legal punishment that is of concern here (i.e., certain negative treatment that can and does follow from legal proceedings) (Williams 1955, 123). Punishment arising in family life, school, or other personal relationships falls outside the general purview.

Since Duff's conceptions will be in focus, it is useful to put forward his definition of punishment. According to Duff, punishment is (typically) something intended to be burdensome and painful, and it is imposed on a supposed offender for a supposed offense by someone with the supposed authority to do so (i.e., the state, state-constituted institutions, agents of the state) (Duff 2001, xiv-xv). ${ }^{4}$

With this definition of punishment in place, the answer to the above question - 'a right to what?' - can be phrased in the following way: The right to be punished is the right of perpetrators to the imposition by stateconstituted institutions of what are generally regarded as burdensome and/or painful consequences for an offense. Burdensome and/or painful consequences typically range from community service, forced incarceration, all the way to the death penalty.

Having provided the contours of Duff's conception of punishment alongside its embracement of the right to be punished, we may now consider the right from the standpoint of the two main theories of rights: the will and interests conceptions.

\footnotetext{
${ }^{4}$ Duff acknowledges that whether pain is a necessary feature of punishment is a controversial matter (see Adler 1992).
} 


\section{The Will Theory of Rights}

On the will theory, rights serve the function of protecting and fostering the autonomy of the right-holder. According to H. L. A. Hart, whose writings are the locus classicus of the will theory, rights count as such only when the right-holder has the option of enforcing or waiving the duty correlative to the right (Hart 1982, 174-193). Famously, the right-holder is a "smallscale sovereign to whom the duty is owed" (Hart 1982, 183). Exercising a right is the measure of the right since "it is hard to think of rights except as capable of exercise" (Hart 1982, 183). One has a right only when one has a degree of control or when one may exercise a choice over the performance of the duty that correlates with the right. On the will-based theory, rights are justified and should be recognized if and only if they protect the exercise of autonomous choice (Hart 1982, 183).

Rights on the will theory serve to foster the autonomy of right-holders. This involves the right-holders' capacity to exercise their rights (e.g., to claim, enforce, leave unenforced, extinguish or waive them) (Hart 1982, 184). Furthermore, following Joel Feinberg, "having rights, of course, makes claiming possible; but it is claiming that gives rights their special moral significance" $(1980,195)$. In other words, what makes an agent a holder of a right on the will theory is the agent's degree of control over the correlative duty that she is owed.

\subsection{Against the Right to be Punished on the Will Theory of Rights}

This section shows that we have good reasons to doubt that the right to be punished can be sustained on the will theory. First, as a coercive practice under the control of the state, punishment does not foster the autonomy of those onto whom it is imposed. Given the coerciveness of punishment, the right cannot be exercised by perpetrators. They can neither claim nor waive their purported right because they lack control over the infliction of punishment. Second, punishment as a threat against would-be perpetrators does not ground a duty on the part of the state to punish perpetrators. This is not to deny that the state has a duty to punish those who violate the law, rather it is to say that such a duty is not owed to law-breakers. It should be borne in mind that the following advances a two-pronged argument against the will theory, which means that the two critiques are meant to be considered as parts of a single, complex argument, highlighting different aspects of examination.

To see why punishment is said to be within the control of the state, as opposed to being within the control of offenders, consider the following: Punishment has been defined as the imposition by someone with 
presumptive authority (i.e., the state, state-constituted institutions, agents of the state) of something intended to be burdensome, unpleasant or painful on a supposed offender for a supposed offense (Duff 2001, xiv-xv). In accordance with the definition, the source of legal punishment is the state, since the state holds the de facto and (presumptive) de jure authority to inflict punishment.

Through its various institutions, the state formulates and enacts rules that, when abrogated, can make one liable to punishment. Once legal rules are in place, their violation can set in motion the criminal process. This process typically involves various stages: arrest; arraignment; pleading; pre-trial motion; criminal trial; sentencing; and, so on. At the trial stage, the judge or jury finds the defendant to be guilty or not guilty (excluding other possibilities, such as mistrials). At the sentencing stage, the appropriate punishment for the convicted is determined. This indicates that agents of the state exercise control over the entire criminal process from arrest to punishment. This, however, does not imply that perpetrators are entirely shut out of legal processes (e.g., they can be heard at trial). Nonetheless, it does suggest that both the liability to incur punishment as well as the actual incurrence of punishment lie within the power of the state.

The kind of control that the state possesses makes punishment a coercive practice, which is to say that punishment is inflicted onto offenders regardless of their will (whether they wish it or not). Furthermore, legal punishment is the most severe form of state coercion, a fact not debated even by those who think it justified (Dubber 2007, 2597). As Hans Kelsen wrote, the coercive nature of the law lies in the fact that it inflicts

an evil-such as deprivation of life, health, liberty, or economic values - which, if necessary, is imposed upon the affected individual even against his will by the employment of physical force. (Kelsen 1967, 33)

Given that the imposition of legal punishment does not take into account the will of the perpetrator, such coerciveness is at odds with perpetrators' autonomy. This represents the first mark against the right to be punished: perpetrators lack relevant control. Even if perpetrators had control over their own punishment, it is hard to imagine circumstances in which an agent would ever claim her right to be punished. Perhaps cases in which some sort of extrajudicial treatment (e.g., lynch mobs) would be more fearsome than legal punishment are plausible examples. In general, though, self-interest would advocate against demanding legal punishment, which would likely be harmful in the short and long term. It is more likely that 
perpetrators would want to waive their right to be punished but any such attempt would be vacuous.

Still, let us consider in what sense a perpetrator could claim the right to be punished and whether the claim would be valid. This takes us to the next prong of the argument. According to the correlativity thesis, claiming this right would be claiming that the state has a duty to punish the perpetrator. With respect to the right to be punished, at least, it is very difficult to discern why such a duty would be owed by the state. The advocate of the right to be punished, abiding by will-based precepts, might answer that a perpetrator who chooses to commit a crime is entitled to punishment because of that choice - that is, because punishment would respect the offender's will and further her autonomy. However, willfully breaking the law does not necessarily mean that a perpetrator wills her own punishment. It is possible (and likely) for an agent to choose to commit a crime all the while not choosing the negative consequences of this (i.e., punishment). That is, in such cases, an agent would simply accept the risk of being punished, not choose to be punished. Accepting the risk that X may occur is not the same as choosing, consenting to, or willing the actual occurrence of X (Thompson 1986, 188). In the case of punishment, it seems plausible (if contentious ${ }^{5}$ ) that offenders are simply hoping not to get caught. The agent is also likely to engage in calculations about the possibility of getting caught and go ahead with the perpetration only if the magnitude of the risk (likelihood of getting caught coupled with the severity of punishment) does not outweigh her expected reward from engaging in the perpetration.

In this respect, having an autonomy-furthering right to choose (even among unlawful options) does not necessarily confer a right to be punished for those choices. If a perpetrator freely chooses to violate a legal rule, she does so knowing that punishment can follow. However, it seems erroneous to conclude that because punishment follows from an individual's wrongful conduct that the state thereby owes a duty to that individual because of her wrongful conduct. This is the case even when such wrongful conduct was freely performed or omitted, and it was known to be wrong at the time of its commission.

The above is in line with a particular view about the nature of legal punishment, which construes the latter as a threat made by the state in order to provide agents with prudential reasons not to break the law. This view is advocated not just by those with utilitarian inclinations (regarding the justification of the institution of punishment), but also by expressivists,

${ }^{5}$ See Nino (1983) and Alm (2018) for alternative views about consenting to the liability to being punished. 
such as Joel Feinberg $(1974,73)$. If this view is correct, ${ }^{6}$ then advocates for the right to be punished misconstrue the nature of punishment itself by (implicitly) regarding the latter as a promise whose fulfillment is owed to perpetrators by the state. Notice about threats that there is no moral obligation to carry them out. As such, the state's threat to punish may not ground a duty (to perpetrators) to punish (Downie 1985, 266).

Again, one peculiarity of the right to be punished is that it is putatively held by a perpetrator, and the correlative duty is owed by a state to that individual. This putative right-duty nexus can easily be misinterpreted as the more plausible thesis that a right is held by the aggrieved. In this sense, the right is rendered as 'victims have the right to have their victimizers punished'. Clearly this version, which provides justice for victims as rightholders, is not the one that is under consideration.

Although Duff believes that not punishing a perpetrator would treat her as less than an autonomous and morally responsible agent, there are other forms of treatment (Duff 2000, 418). These could aim to restore the agent and help guide her future conduct without appeal to suffering. There is nothing in some alternatives to punishment that renders them necessarily incapable of treating agents with due respect. Whether punishment, too, can treat agents with due respect is at the heart of its justifiability and must be shown to be the case. The case of alternative responses (other than punishment) will be addressed in the next section as well.

The two sources of criticism advanced in this section show that the right to be punished encounters serious difficulties on the will theory. The firstthe coerciveness of punishment seriously diminishes the autonomy of perpetrators - coupled with the second - there seems to be no duty owed to perpetrators by the state - offer good reasons to doubt that the right can be sustained. However, this does not yet spell doom for the right to be punished. The interest theory might be able to provide it with proper grounding. This possibility is considered next, and it is rejected.

\footnotetext{
${ }^{6}$ Here, Lipkin's (1988, 92-93) criticism of Duff's communicative theory is helpful in pointing out the advantages of prudential theories. Lipkin criticizes Duff's view on the grounds that it fails to provide a general motive to obey the law, and asserts the superiority of prudentially-based theories that are able to draw in every rational person regardless of their morality by providing them with prudential reasons for obedience.
} 


\title{
3. The Interest Theory of Rights
}

Within the interest theory, rights are grounded in the interests of the rightholder. On one of the most prominent versions of the theory, Joseph Raz's account,

\begin{abstract}
' $\mathrm{X}$ has a right' if and only if $\mathrm{X}$ can have rights, and, other things being equal, an aspect of X's well-being (his interest) is a sufficient reason for holding some other person(s) to be under a duty. (Raz 1986, 166)
\end{abstract}

Broadly speaking, rights on the interest theory serve to benefit rightholders. If the right to be punished is to be sustained on this theory, it is by virtue of perpetrators' interests in being punished. Notice that such interests must be sufficient to ground a duty in the state to inflict punishment. There are, then, two distinct conditions for establishing the right to be punished on the interest theory: first, punishment advances the interest(s) of perpetrators; and, second, the interest(s) are sufficient to ground a duty in the state. This section aims to show that the right to be punished on the interest theory fails because of the many and serious doubts surrounding the satisfaction of both conditions. It should be borne in mind that although the first and second conditions are treated separately for the sake of clarity, the two must hold in conjunction in order for the right to be punished to be properly supported by the interest theory. This is important because the success of only one of our criticisms (i.e., either against the first or second condition) is sufficient for our purposes.

\subsection{Against the View that Punishment Advances Perpetrators' Interests}

To speak of interests, and then to connect these to rights, some notion of interests is needed. Duff makes a case in favor of the right to be punished on the grounds that it is for the good of the perpetrators and accords with their autonomy. ${ }^{7}$ His view is that punishment is beneficial to perpetrators because it is a way for them to repent for their crimes, which achieves selfreformation and reconciles them with the communities whose norms they violated and to which they belong (Duff 2001, 107). ${ }^{8}$ This description

\footnotetext{
${ }^{7}$ In the preceding section, the commitment to autonomy was analyzed in connection with the will theory. However, it can also be construed as being in the interest of a perpetrator. Thus, the right to be punished may also be grounded in perpetrators' interest in autonomy, which is purportedly advanced through punishment. Part of the preceding criticism would speak against such a claim.

${ }^{8}$ The aims of punishment on Duff's theory will henceforth be referred to as the three Rs.
} 
succinctly captures what Duff regards as the ideal aims of punishment, which he also calls the three Rs of punishment.

Given the above, the right to be punished can be said to protect the interest that perpetrators have in being punished. To this, it seems fitting to rely on that which punishment can and ought to secure, inter alia, for the good of the perpetrators (at least according to Duff's theory): repentance, reform and reconciliation. Thus, arguably, perpetrators could be said to have a right to be punished because punishment can protect and secure the interests that they have in the three Rs. Given this interpretation of Duff's conception, it seems fair to assess the right to be punished in relation to the specific interests that it should serve - the three Rs. We will continue to operate with this conception of interests in being punished and consider the plausibility of the first condition-roughly, that punishment advances perpetrators' interests - in light of it.

For the first condition to be true, it must be the case that being punished advances the three Rs of perpetrators. Firstly, this means that the three Rs must be in the interest of perpetrators in the first place. Secondly, this means that the benefits of securing the three Rs outweigh the cost of punishment for perpetrators. $^{9}$

The first, determining whether the three Rs are interests of (all) perpetrators, is hardly a straightforward matter. Duff's discussion of different types of ideal offenders, such as the morally persuaded, repentant, and defiant offenders, proves useful in highlighting the different perspectives on punishment that individuals may take (Duff 2001, 116124). One such ideal type is of the defiant or principled offender. This class of perpetrators affords the clearest source of doubt for the claim that all perpetrators have an interest in the three Rs (Duff 2011, 374).

Principled offenders are individuals who commit an offense on the basis or for the purpose of expressing their moral convictions or conscientious objection. The problem here stems from the fact that if such offenders reject community's values (as some would), then they would have little reason to pursue the path towards repentance, reform or reconciliation-in other words, they would have little interest in being punished. In such cases, Duff believes that there will be other grounds that will still justify

\footnotetext{
${ }^{9}$ While there is room for debate on this, benefit is here taken to be an overall increase or improvement relative to costs. Where $\beta=$ benefits, and any integer above 0 expresses such an increase, then $\beta>0$. Again, how much of an increase and determinations about whether there has been (in fact) or will be an increase is debatable. Part of the aim in treating interests in this way is to highlight the extent to which such contingencies need definition in order to justify the right to be punished, and punishment itself (at least on Duff's account).
} 
their punishment, such as the community's and victim's interests (Duff 2001, 123). However, this would mean perpetrators' interests, which would, in turn, ground offenders' right to be punished, might be off the table. Not so, however, because Duff insists that punishment is owed even to such principled offenders out of respect for them as moral agents, as members of the moral community (Duff 2001, 123).

However, the insistence that punishment is owed to principled offenders is difficult to square with the idea of respect for persons and their autonomy, which Duff rightly treasures. At least in the case of some principled offenders (e.g., whistleblowers, dissidents, and political activists), it is hard to see how their autonomy could be respected and a charge of paternalism avoided. This is because on Duff's view, autonomy appears divorced from perpetrators' actual system of practical reasons, their autonomous decisions or desires (Lipkin 1988, 97). Instead, as Robert Justin Lipkin $(1988,97)$ argues, Duff seems to be portraying autonomy as the autonomy to be moral whether one wants to be or not. Lipkin $(1988,97)$ contends that this is a peculiar view to advance given that autonomy must be connected to individual wants. Moreover, if this were not the case, then one could claim to be acting out of respect for and on the basis of offenders' autonomy without taking into account any of their desires and, then, any kind of punishment could be justified on such bases (Lipkin 1988, 97).

Having noted these concerns, let us nevertheless suppose that the three Rs are interests of perpetrators. This brings us to the second issue about the first condition. The question becomes whether punishment can advance the three Rs in such a way as to offset its costs. The modest claim is that punishment does not necessarily do so; contingencies pertaining both to perpetrators and the modes of their punishment affect whether punishment is able to meet this condition. Particularly when it comes to punishment such as incarceration the thought that the satisfaction of the three Rs will necessarily outweigh the costs incurred in their pursuit is far from obvious. Furthermore, since success in achieving the communicative aims of punishment is not built into Duff's theory, it is the benefit of making the attempt to secure the three Rs that should be weighed against the costs of making the attempt. It is far from clear how to go about calculating the expected benefits of the three Rs against the, sometimes devastating, costs of such punishment.

Moreover, accepting that the right to be punished exists for all perpetrators qua perpetrators (and that being a perpetrator confirms an interest in this right), would require us to set aside and disregard the unique moral situation of individual perpetrators. Regardless of character, severity of crime, mode of punishment, and so on, perpetrators would seem to have an 
interest in and a right to be punished. However, the case of principled or defiant offenders speaks against a blanket generalization of this kind.

Duff believes that a perpetrator has a right to that degree of punishment sufficient to advance her three Rs. He writes:

If we care, as we should, both about the burdens that punishment of its nature imposes and about the danger that those burdens will be excessive or harmful, we should accept a principle of penal parsimony, which requires us to impose punishments no harsher (in mode or amount) than is strictly necessary for the aims that punishment is to serve. (Duff 2001, 134)

Thus, the mode and the degree of punishment that should be administered is qualified and appears to be that which would seem necessary to secure the three Rs of the perpetrator (under proportionality constraints). This view, however, assumes an otherwise questionable harmony between the three Rs. There is the possibility that for any given perpetrator the three Rs could conflict when it comes to the mode or extent of punishment that could secure them. What should we say of a perpetrator whose interest in self-reformation would be sufficiently advanced by a lenient sentence (e.g., because of facts about her character) but whose interest in reconciliation with the community would only be sufficiently advanced by incarceration (e.g., because of the severity of her crime or because the community's norms are particularly demanding)? The above does not refute the existence of the right to be punished, but gives rise to doubts regarding its sustainability on the basis of the interests of perpetrators that take the form of the three Rs.

The right to be punished faces yet another problem. Perpetrators may be said to have an interest in the three Rs (e.g., making amends and being reintegrated into society), but why that should necessarily involve punishment is decidedly unclear. That being said, Duff believes that punishment is necessary. He writes:

But it is not a contingent matter that punishment-the infliction of suffering on an offender for her offense - is the appropriate way of trying to achieve the kind of penitential reform which is its justifying aim: that aim, can of its nature, be achieved only by bringing the offender to suffer for what she has done. If someone suggested, for instance, that we might hope to develop some kind of drug or psycho-surgical technique which would provide a more efficient and less 
painful method of securing the kind of reformative change at which punishment aims, we would not need to question the empirical plausibility of her suggestion: for the suggestion itself is incoherent. No such technique could, logically, produce the results at which punishment aims: such techniques do not address the criminal, as punishment must address her, as a responsible moral agent who can and should come to understand the moral implications of what she has done; they are not, as punishment must be, attempts to solicit and arouse her repentant understanding of her crime; and the acquisition of such an understanding must of its nature be painful to the criminal. (Duff 1986, 262) ${ }^{10}$

One can reasonably interpret Duff as advocating for a rather unsavory view that might be captured as 'persuasion through pain'. Duff's definition and conception of punishment necessarily involves pain, and pain is regarded by him as indispensable if perpetrators are to come to understand their crimes. The above excerpt is not only illuminating, but still fairly consistent with Duff's more recent writings at least when it comes to retaining the element of pain. In particular, in Punishment, Communication and Community, he preserves the emphasis on the pain and suffering perpetrators should feel as inducement to repentance:

Repentance is $[\ldots]$ an aim internal to censure. [...] Repentance is necessarily painful, since it must pain me to recognize and admit (to myself and others) the wrong I have done. In aiming to induce repentance, punishment thus aims to bring offenders to suffer what they deserve to suffer - the pains of repentance and remorse. (Duff 2001, 107)

But, why should persuasion involve pain? Surely there are other ways to persuade someone to understand the gravity of her actions. It is true that pain might be a part of atonement in the sense that once a perpetrator understands her wrongdoing (e.g., the pain she has caused victims) she should feel remorse, maybe even psychological pain. However, there are at least two ways in which such an understanding of pain seems to differ from Duff's and from the rationale of punishment generally. First, on this view, pain would come as a result of atonement, not as a means to it. Second, pain would not be inflicted upon a perpetrator to make her

\footnotetext{
10 The view presented in the paragraph comes from Duff's earlier work. However, even in more recent works such as Duff $(2001,107)$ and Duff $(2003,186)$, he maintains that some forms of punishment are intrinsically appropriate as censure and "censure is intended to hurt".
} 
understand her crimes; rather, pain would be something a perpetrator comes to feel on her own.

Some of Duff's reasons for seeing pain as necessary seem to revolve around the fact that without it we would not address the criminal as a responsible moral agent. He points out that other ways of addressing perpetrators fail in this way. However, it is strange that the alternatives to punishment that Duff chooses to highlight are extreme ones. Drugs and psycho-surgical techniques are hardly the first things that come to mind as plausible substitutes. Agents could come to understand and make amends for their crimes in myriad other ways that would not involve punishment (e.g., therapy, financial reparations, or a combination of these).

Therapy, for instance, could achieve the same three Rs without the pain and suffering that is necessarily involved in punishment. Here, it is not sufficient to claim that other treatments would deny the status of perpetrators as morally responsible and autonomous beings; alternatives to punishment, such as therapy, would be presented to perpetrators because they committed crimes and potentially with the same aims that Duff has in mind. ${ }^{11}$ Further, the autonomy of individuals could be better protected if they were left to choose one of these alternatives for themselves, with prior and/or subsequent approval by a state body.

The fulfillment of the first condition was the first hurdle for establishing the right to be punished on the interest theory. In accordance with Duff's account, meeting this condition requires showing that the right advances the three Rs of a perpetrator. However, the above showed that there are reasons to doubt that the right to be punished can satisfy this condition. Furthermore, it is worth remembering that the first condition must be met in conjunction with the second, which means that success in undermining either is sufficient to dispel the notion of a right to be punished on this view.

\subsection{Against the View that Perpetrators' Interests in Punishment are Sufficient to Ground a Duty in the State}

We now turn to the final piece of the argument. Given the preceding and the nature of claims in this subsection, the following will be brief but conclusive. The second condition for establishing a right to be punished requires that perpetrators' interests in being punished are sufficient reasons

\footnotetext{
${ }^{11}$ See Lacey and Pickard (2013) for a thoughtful discussion and defense of the clinical model of responsibility that takes the therapeutic ends of punishment seriously without thereby effacing moral agency.
} 
to ground a duty in the state to punish them. As discussed at the beginning of this section, an agent has a right if and only if a certain aspect of her well-being (i.e., an interest) is a sufficient reason for holding others to be under a duty (Raz 1986, 166-172).

Setting aside problems about determining whether punishment advances interests of perpetrators from the preceding subsection, claiming that such interests (e.g., in reconciliation, in self-reformation, in being treated as moral agents, and so on) can ground a duty to punish on the part of the state is based on a confusion about the kinds of reasons that these interests can provide. That is, interests in being punished can provide reasons in favor of punishment, but they cannot provide sufficient reasons in favor of punishment. To see why, consider the following.

Rights on the interest theory can be justified on the basis of their instrumental value in securing or promoting individuals' interests. However, not all interests can give rise to rights. Determining which interests are sufficient to ground rights necessitates, among other things, probing into the correlative of the purported right - the duty that it would establish. In other words, for our purposes, the question is: Are perpetrators' interests, namely the three Rs, sufficient to establish a duty on the part of the state? The following will seek to show that this is not the case.

To start, the current practice of legal punishment demonstrates that the state does not act as if it were under a duty. To see this, consider that legal punishment is a result, a form of treatment, which follows from legal judgment. Before judgment, the state is not considered to owe perpetrators punishment because it is not clear whether this legal response ought to be brought against them.

Throughout the legal process the state retains the power to impose punishment or not. If the state were considered to be under a duty to punish or indeed had a duty to punish, then not punishing perpetrators would amount to wronging them. In such cases, it is possible that a perpetrator could demand to be compensated for the wrongdoing suffered. In those instances when the state chooses not to punish it is clear, however, that no wronging against the perpetrator is considered to have been committed.

To put matters differently, the claim that perpetrators have a right to receive a result (i.e. punishment) is dubious because, ex ante, it is not clear whether this should be imposed on them. The matter of punishment is determined after deliberation, which involves weighing considerations that include, but are not limited to, a perpetrator's interests. If, however, 
perpetrators' interests were sufficient to determine the duty of the state to inflict punishment, then the state would, ex ante, find itself under a duty to punish.

The nature of punishment is such that organs of the state may choose not to punish a perpetrator (e.g., offer her pardon or some form of response other than punishment) or punish her to a greater or lesser extent (e.g., symbolic punishment, long sentence). Even though much is known about the likelihood of a perpetrator suffering punishment, whether or how much punishment is to be applied remains a case-by-case matter. For instance, whether to pursue punishment or how much punishment to inflict is within state agents' discretionary powers. Discretion means that cases may be dropped, charges changed, or punishment forsaken for a variety of reasons (e.g., preserving social order, victim's preference). ${ }^{12}$

Although the interests of perpetrators might serve as pro or contra reasons when deciding whether to inflict punishment, the preceding subsection underscored that the advancement of interests that take the form of the three Rs through the infliction of punishment is questionable. Furthermore, even if we can determine that perpetrators' interests will be advanced, such considerations are only some out of the multitude of reasons that organs of the state ought to take into account. Thus, assuming that such interests obtain, they do not constitute sufficient reasons in favor of or against punishment.

Recall that for the right to be punished to exist on the interest theory, it must be the case that perpetrators' interests in being punished constitute sufficient reasons for grounding a state's duty to punish them. However, examples that show the interests of perpetrators to be insufficient considerations are easy to find. For instance, a dissident might have an interest in being punished, but the state knows that punishing her would result in widespread violence. The state might then rightly decide not to punish the dissident because, all things considered, the right course of action dictates against punishing her. In order to make the point we need not rely on hypotheticals alone. Real and even high-profile examples are also available. Gerald Ford offered Richard Nixon a full pardon on the grounds that Nixon had already suffered enough by relinquishing his office (see Ford 1974). Other considerations, such as age, health, suffering of dependents, may also affect the extent (if at all) of sentencing. These considerations point to the fact that interests of perpetrators might constitute reasons to punish (or not), but they are certainly not determinant ones.

${ }^{12} \mathrm{We}$ wish to thank an anonymous reviewer for these helpful points. 
The above is more than descriptive of a state of affairs: perpetrators' interests are among the many reasons to be considered, but they should never be more than that. This is because claiming that the advancement of interests of those who commit crimes are sufficient to establish a duty for the state to punish would mean that it is not necessary for the state also to consider other interests (e.g., victims' interests, societal interests, or yet other interests) for it to find itself under a duty.

Take Raz's theory, where an agent may be said to have a right if and only if some aspect of her well-being (some interest of hers) is sufficiently important in itself to justify holding some other person or persons to be under a duty. It should be noted that because of how counter-intuitive it would be to suppose that agents have an interest in punishment in itself, we assume that any right in punishment would be based on other interests (e.g., the three Rs). This means that the right would not be a core right, but rather one derived from other aspects of individual well-being.

Having specified what it means to have a right in accordance with the above version of the interest theory, it is also important to identify the conditions that determine the absence of a right. According to Raz, if conflicting considerations show that the interests advanced or protected by a purported right are not enough to justify subjecting anyone to any duty, then the right does not exist.

Raz writes: "where the conflicting considerations altogether defeat the interests of the would-be right-holder, or when they weaken their force and no one could justifiably be held to be obligated on account of those interests, then there is no right" (Raz 1986, 183-184). Furthermore,

only where one's interest is a reason for another to behave in a way which protects or promotes it, and only when this reason has the peremptory character of a duty, and, finally, only when the duty is for conduct which makes a significant difference for the promotion or protection of that interest does the interest give rise to a right. (Raz 1986, 183-184)

One of the most damaging marks against the existence of the right to be punished is that if the right exists, then the interests protected by it would have to be sufficient to ground a duty on the part of the state. Furthermore, the nature of duties is such that they provide not just reasons for action of significant weight. Duties give rise to exclusionary reasons that have a special peremptory force ( $\operatorname{Raz} 1986,195)$. Thus, the state would have an exclusionary reason to inflict punishment (see Raz 1975; 1979; 1986; $1989 ; 1990)$. This means that the state would have a second order reason 
to punish offenders that excludes acting on and perhaps even considering first order reasons that go against punishment.

The above could be a rather unwelcome conclusion as other considerations (such as the interests of dependents, victims, or society) ought to play a role in deliberation and state action. It is not unusual for interests to come into conflict, which means that to regard perpetrators' interests as grounding duties that altogether displace other reasons is problematic.

We do not have good reasons to correlate the interests of perpetrators with a duty to punish of exclusionary force if this would mean that victims' and society's interests would, thereby, have to be put to the side. One might think that interests of victims, perpetrators, and society are compatible, but that is not always the case. Furthermore, even if one assumes these interests to be compatible there remains something uneasy about inflicting punishment for reasons that by definition could exclude the interests of victims, society, and others.

This is not to say that perpetrators' interests ought not to be considered or that they ought to weigh less than other reasons. Perpetrators' interests should be considered during deliberation and judgment. However, if we grant the existence of the right to be punished, then it follows that the interests of perpetrators (e.g., the three Rs) will ground the preemption of other reasons. It is this latter ramification that is challenged.

The above considerations capture the second condition's main failings. Since interests of perpetrators cannot and should not be sufficient considerations in favor of punishment, the state is not under a duty to punish. Furthermore, this conclusion would hold even if we were to cash out perpetrators' interest in punishment in a different way (i.e., other than the three Rs). Thus, it becomes clear that the state does not owe punishment to perpetrators based on their rights to it.

\section{Conclusions}

As noted in the introductory paragraphs of this article, the idea of a right to be punished has been around for quite some time. Its longevity clearly does not represent an argument for favoring it. This article has shown that even in its more recent iterations, notably from Duff, the idea of a right to be punished is far from secure. In fact, it has been shown that on the willbased and the interest-based theory of rights, there are strong reasons to disregard the right to be punished as anything but an outmoded or misguided notion. On the will theory the right to be punished was shown 
to be at odds with the autonomy of (purported) right-holders, while on the interest theory serious doubts were presented regarding the (alleged) right's ability to serve its function as promotor of offenders' interests that are sufficient to ground a duty to punish on the part of the state.

One final point is about how this work advances the state of the discussion. The ongoing conversation about legal punishment continues unimpeded and many of the long-standing debates remain as contentious as ever. This article ultimately helps to show that while there are many questions about punishment worth examining, the question about a (purported) right to be punished might be best laid to rest. Clearly, the other questions about punishment were left unexamined in any thoroughgoing way because the aim of this paper was narrower. We examined one question - right to be punished?-so that those others may be more profitably investigated elsewhere.

\section{Acknowledgments}

The authors wish to thank two anonymous reviewers for their careful readings and helpful suggestions and comments.

\section{REFERENCES}

Adler, J. 1992. The Urgings of Conscience: A Theory of Punishment. Philadelphia: Temple University Press.

Alm, D. 2018. Punishment, consent and value. Ethical Theory and Moral Practice 21: 903-914.

Bagaric, M., and K. Amarasekara. 2000. The errors of retributivism. Melbourne University Law Review 24: 124-189.

Bennett, C. 2008. The apology ritual: A Philosophical Theory of Punishment. Cambridge: Oxford University Press.

Brooks, T. 2013. The right to be punished: A defense. Legal Theory in China 3: 21-39.

Deigh, J. 1984. On the right to be punished: Some doubts. Ethics 94: 191211.

Downie, R. S. 1985. Three accounts of promising. The Philosophical Quarterly 35: 259-271.

Dubber, M. D. 1998. The right to be punished: Autonomy and its demise in modern penal thought. Law and History Review 16: 113-146.

Dubber, M. D. 2007. Punishment, morality, and the state: Legitimating penal law. Cardozo Law Review 28: 2597-2613. 
Duff, R. A. 1986. Trials and Punishments. Cambridge: Cambridge University Press.

Duff, R. A. 2000. In defense of one type of retributivism: A reply to Bagaric and Amarasekara. Melbourne University Law Review 24: 411-426.

Duff, R. A. 2001. Punishment, Communication, and Community. Oxford: Oxford University Press.

Duff, R. A. 2003. Penance, punishment and the limits of community. Punishment \& Society 5: 295-312.

Duff, R. A. 2011. In response. In Crime, Punishment, and Responsibility: The Jurisprudence of Antony Duff, eds. R. Cruft, M. H. Kramer, and M. R. Reiff, 351-379. Oxford: Oxford University Press.

Feinberg, J. 1974. Doing and Deserving: Essays in the Theory of Responsibility. Princeton: Princeton University Press.

Feinberg, J. 1980. Rights, Justice, and the Bounds of Liberty: Essays in Social Philosophy. Princeton: Princeton University Press.

Ford, G. R. 1974. Proclamation 4311 - Granting Pardon to Richard Nixon. September 8, 1974. https://www.fordlibrarymuseum.gov/library/speeches/740061.a sp.

Hallevy, G. 2013. The Right to Be Punished: Modern Doctrinal Sentencing. Berlin: Springer-Verlag.

Hart, H. L. A. 1982. Essays on Bentham: Studies in Jurisprudence and Political Theory. Oxford: Clarendon Press.

Husak, D. 2008. Overcriminalization: The Limits of the Criminal Law. New York: Oxford University Press.

Kelsen, H. 1967. Pure Theory of Law. Berkeley: University of California Press.

Lacey, N., and H. Pickard. 2013. From the consulting room to the court room? Taking the clinical model of responsibility without blame into the legal realm. Oxford Journal of Legal Studies 33: 1-29.

Lipkin, R. J. 1988. Punishment, penance and respect for autonomy. Social Theory and Practice 14: 87-104.

Nino, C. S. 1983. A consensual theory of punishment. Philosophy \& Public Affairs 12: 289-306.

Penner, J. E. 1997. The analysis of rights. Ratio Juris 10: 300-315.

Raz, 1975. Practical Reason and Norms. Princeton: Princeton University Press.

Raz, J. 1979. The Authority of Law. Cambridge: Cambridge University Press.

Raz, J. 1986. Morality of Freedom. Clarendon: Oxford University Press. Raz, J. 1989. Facing up: A reply. Southern California Law Review 62: 1153-1235. 
Thomson, J. J. 1986. Rights, Restitution, and Risk: Essays in Moral Theory. Cambridge: Harvard University Press.

Williams, G. 1955. The definition of crime. Current Legal Problems 8: 107-130. 
Adriana Placani and Stearns Broadhead 